DOI https://doi.org/10.36059/978-966-397-216-9/102-120

\title{
INTERPRETATION OF IDENTITY IN THE DISCOURSE OF CULTURAL STUDIES
}

\section{Uvarova T. I.}

\section{INTRODUCTION}

At present, the problematic field of cultural studies has acquired a meta-scientific, transdisciplinary character, which may be explained by the universality of culture as a "spiritual ether" that penetrates all aspects, facets, and modi of human and social being. Cultural studies help to comprehend and recomprehend the relation between cultural traditions and innovations, the role of norms and values, patterns and ways of behavior; by means of inculturation, they help to hold society within the framework of a positive social being. This quality of cultural knowledge is particularly relevant because of the current anthropogenic crisis, caused by the growth of technogenic impact and intense growth of the diversity of cultures that enter the historical arena as independent entities. While contemplating on scenarios of future world development, cultural studies refer to the category of identity as a basic concept that reflects certain cultural-determined ideas a person has about the world.

Therefore, our observations prove that a significant trait of modern culture is the formation of its new image along with the traditional one. The traditional image of world culture is associated, first of all, with the ideas of its historical and organic integrity, ideas about norms, rules, traditions, customs and so on. The new image of culture is increasingly associated with the development of noosphere, planetary thinking, ideas of ecohumanism and universalism; it implies the gradual rejection of simplified rational schemes for resolution of cultural problems, the growing role of understanding reflection regarding unfamiliar cultures, the recognition of the plurality of truths' legitimate existence. In this study we applied the methodological toolkit of cultural science represented by empirical and theoretical research methods (system, cultural, analytical approaches) with an attempt to distinguish cultural identity and to define it as a basic concept of cultural studies, to determine theoretical concepts of identity formation, including national, and to distinguish and explore the 
specifics of Ukrainian cultural identity. We also analyzed the contemporary challenges and perspectives of identity which formation is strongly influenced by globalization and technology.

\section{Cultural identity within the problematic field of cultural studies}

Today, the conceptualization of identity has a central position in the arsenal of cultural studies. This enlargement of the conceptual apparatus of cultural studies is explained by the expansion of knowledge about culture and new developments in the research of the very concept of "identity".

The concept of "identity" comes from Latin identifico, which can be translated as "sameness". The problem of identity is caused by the needs in the practice of becoming (formation and development) a person in full compliance with hisher inner nature and essence, entering into the social and cultural world. As a social being, a person is formed in the cultural field, in the environment of personalities endowed with certain human features. Accession into this world is a process of acquiring its typical qualities, socialization of existing knowledge and cultural norms. A person tries to learn them, adopt them, transform them into own characteristics, and to become similar to other people who exist nearby. At the same time, individuals try to realize their self, that of a special human being, identical only to them. By "privatizing" qualitative characteristics, taken from others, by expanding their peculiarities given by nature, individuals realize themselves as personalities belonging to a particular community. Simultaneously, this process is a process of self-identification of the individual - assimilation, identification (with society and themselves), selfawareness as similar to others and, at the same time, as a special unique personality - "I". But let us note that the process of identity formation is not a separate single act, it is a series of interrelated choices whereby a person accepts one's own goals, values, and beliefs.

In cultural theory, the concept of identity expresses the identification of an individual with a particular cultural tradition. Cultural identity is a person's sense of self-awareness within a particular culture, conscious perception of norms and patterns of behavior, a system of values and language, as well as the realization of one's "I" in a particular cultural dimension. Cultural identity implies the formation of sustained qualities of an individual, due to which certain cultural phenomena or people provoke sympathy or dislike; depending on this a person chooses the appropriate type, manner, and form of communication. 
Cultural studies have an axiom that each individual bears the culture in which he or she has grown and formed as a person. In everyday life a person does not notice specific features of own culture, taking them for granted, however, when meeting with representatives of other cultures, these features become apparent and the person realizes that there are other forms of experiences, behaviors, ways of thinking that are significantly different from the usual and familiar. A person's mind transforms various impressions about the world into ideas, attitudes, stereotypes, expectations, which eventually become for his regulators of personal behavior and communication.

Any group always has an inherent cultural core (the main marker of cultural self-identification), which gives coherence to the actions of its members and manifests itself externally through various modifications. Analyzing cultural self-identification, we must take into account the objective (external) and subjective (internal) factors that influence the development of this process. Objective factors include the existence of a particular group of people, the territory where they are located, language (dialects), historical memory, means of existence, customs, rituals, traditions, patterns of communication, etc., which act as determining factors that define membership or the individual's belonging to particular social groups throughout their existence. Subjective factors include stereotypes, beliefs, symbols, rituals, behavior, consciousness, etc. From an intra-group perspective, identity is based on a complex of cultural features that differentiate members of one group from all other groups, even if they are culturally close enough. Therefore, a coherent, solidary motivation of individual group behavior is formed. One's cultural identity is formed through association with existing cultural orientations and role functions.

The concept of cultural identity is connected with the stages of ethnos' development, its system of sign and symbolic representations and assessments of the world and forms of cultural and historical existence. Ethnos is a cultural and spiritual community of people, related in origin, language, cultural heritage, a common territory of residence. Ethnic identity is "the result of an emotional and cognitive self-identification of a subject with his ethnic group, expressed in a sense of community with members of that group and perception of its core characteristics as values" ${ }^{1}$. It includes a person's perceptions of

${ }^{1}$ Гнатенко П. И., Павленко В. П. Ідентичність: філософський i психологічний аналіз, Київ, 1999. 100 
their ethnic group, and feelings and intentions associated with those perceptions. National myths, symbolism, historical memory are all necessary factors of any identity. The brightest evidence of ethnic formations' viability is their existence in today's multifaceted society. Ethnic groups who nurture ethnic self-consciousness and maintain collective identity are the main representatives. We define an ethnic group as a group of people which has some specific ethnic, cultural, linguistic, religious, racial traits, united by total or partial origin. Ethnic group members consider themselves culturally different. According to A. Giddens, to identify ethnic groups we should consider such characteristics as language, history or origin, religion, culture ${ }^{2}$. A compulsory basis for ethnic identity is the community of culture. Basic values, by forming a cultural basis, determine the rules of relations, set priorities, assessments, goals.

The American researcher E. Erickson considered the acquisition of identity as a necessary process associated with social adaptation. He also offered the term "identity crisis" (this term has become widespread in the 1950 s as a general characteristic of the modern era) ${ }^{3}$.

In the context of essential contemporary transformations in culture, the problem of identity receives particular relevance. A particular fact of cultural identification existence is the possibility of its loss by the individual. The loss of cultural identification is revealed through alienation or marginalization. The category "marginality" (a term introduced by the American sociologist R. Park) is used in cultural studies to describe the borderline status of a person in relation to a particular social community, which imposes a certain footprint on person's mind and lifestyle. The so-called "cultural hybrids" find themselves in a situation of marginality, balancing between a group that dominates society but to which they have never belonged and a group from which they have separated.

Transforming identity gives rise to new connotations such as, for example, the "economy of identity". That means, how our ideals and social norms determine who we work as, how much we earn, what our level of financial capacity is, and so on. It is obvious that business is oriented towards identity: activities are directed to create recognizable images of territories, cultural brands and so on. Institutions of

${ }^{2}$ Гидденс Э. Социология, Москва, 1999. 235.

3 Эриксон Э. Трагедия личности, Москва, 2008. 157. 
socialization, like education system, cultural and educational initiatives of different levels appeal to identity as the basis for consolidation of modern society.

Research of identity is also of high priority for political science. Identity policy (claim of minority groups the right to own value systems and behaviors) is a part of social movements. Political conflict, political technologies, public policy, etc. give priority to studies of identity. The conceptualization of political identity becomes one of the foundations for a new direction of interdisciplinary research - socio-political cultural studies. Developing a scientific toolkit for identity research can contribute to political forecasting and reduce the risks of social development in future.

So, identity is a phenomenon that arises from the interconnection of the individual, society, and culture. Identity research plays a key role in the problematic field of cultural studies. But the problem of the interdisciplinary origin of identity also begets the problem of its discursive accumulation. Despite the relatively high amount of research literature, the problem of identity, particularly in the context of globalization and the information revolution, has not yet been fully explored.

\section{Theoretical concepts of formation of national identity}

The formation of national identity is one of the central issues in contemporary Ukrainian culture. National identity is the lens through which many relevant aspects of life are considered, evaluated and explored.

Identity research takes place within a cognitive paradigm that recognizes both the diversity, uncertainty, and multiplicity of approaches of this concept, as well as the diversity of aspects that influence its formation. But it is not always possible to talk about the unity of approaches. This issue is irrelevant for Ukrainian science for several reasons: a relatively short scientific tradition, the modern Ukrainian nation is young and unsteady, so such concepts as "national identity" are relevant and need to be understood, and the events of recent years demonstrate that modern Ukrainian nation is still forming.

Researchers define the national identity as a set of features that unite certain communities within national borders and as internal traits that determine the process of self-identification, distinguishing from other nations. The category of "national identity" as one of the basic theories of the nation derives from the understanding of what a nation is. Probably the most practical definition of the nation was given by 
B. Anderson, who noted that the nation is "an imagined political community has imagined as both inherently limited and sovereign" ${ }^{4}$. In other words, we call a nation a community of people with a common geography of residence, a shared past and a projection of the future, and as B. Anderson noted, a nation in our understanding is a community in which people in the remotest corners of the country identify themselves with thousands of people like them, never knowing each other personally ${ }^{5}$.

The term "identity", while having a Latin origin, can be replaced synonymously by uniformity, sameness or originality. As sameness, identity is the features that unite representatives of one nation within society. As originality, identity is what distinguishes the nation apart from others. The modern theory of nations identifies two main areas of understanding of the nation and national identity: ethnic and political. Primordialists, or in other words proponents of the ethnic theory, argue that the identity of nations is formed on an ethnic basis, however, the supporters of the political theory see the nation's core not in the ethnos, but in the political consolidation achieved through the integration of people through high levels of political activity and state influence on society. For representatives of political theory, the concepts of "nation" and "state" are identical. We should note that each approach is not considered universal. For the modern understanding of national processes, they are complementary.

The concept of "national identity" is a combination of objective and subjective features of a particular nation. The only correct definition of this phenomenon does not exist. However, most researchers find that this phenomenon unites the communities of people in the nation through a set of signs or attributes, and distinguishes it from others by forming collectivity within the community.

The Ukrainian researcher G. Kasyanov uses the term "national consciousness" along with the concept of "identity", claiming that" this is first and foremost a self-representation as a national community, a nation. When one considers himself or herself to be part of such a community, we may claim the fact of the existence of national consciousness" $^{6}$. National identity is a certain key to understanding the

${ }^{4}$ Андесон Б. Уявлені спільноти: міркування щодо походження і поширення націоналізму, Київ, 2001. 22.

${ }^{5}$ Ibid. 22-23.

${ }^{6}$ Касьянов Г. Теорії нації і націоналізму, Київ, 1999. 352. 
essence of a nation. It manifests itself through certain parameters, or in other words "identity markers". Acknowledged researcher of the theory of nation E. Smith defined national identity as a complex construction, noting that it consists of "many interconnected components - ethnic, cultural, territorial, economic and political-legal" ${ }^{7}$. He identified the features that indicate the phenomenon of national identity: "Historic territory or native land; shared myths and historical memory; shared civic culture; common rights and responsibilities for all members of society; common economy, the ability to move freely within the national territory" ${ }^{8}$. In general, the modern scientific tradition identifies the following sources of identity: the psychological belief that a nation exists because all members of society recognize it and plan to coexist; a shared historical past, present, and future; joint actions; belief in a common motherland (territorial marker); common features: national culture, political principles, etc. It is obvious that nations are formed structures, however, they change and evolve over history, so the markers of national identity are not established, they vary depending on specific realities.

In our view, in the context of the problem of defining national identity, the theoretical concepts outlined by S. Huntington in his work "Who Are We? The Challenges to America's National Identity" are of particular interest ${ }^{9}$. He stated that identity is the self-awareness of an individual or group which is a product of self-identification, an understanding of possessing unique qualities that "differentiate me from you, us from them. As long as people interact with their environment, they have no choice but to define themselves through relation to others and to identify the revealed similarity and difference" ${ }^{10}$.

Huntington offered to structure identity, distinguishing the basic theoretical concepts of its formation. First of all, in his opinion, both individuals and groups are endowed with identity. Also, individuals can change the acquired identity only in groups. An individual can be a member of many groups and have the ability to "switch" his identities. Group identity is, as a rule, less flexible.

In Huntington's theory, identities are constructs. People construct their identities, either by necessity, by choice, or by coercion. "Identities

\footnotetext{
${ }^{7}$ Сміт Ентоні Д. Національна ідентичність. Київ, 1994. 24.

${ }^{8}$ Ibid. 51.

${ }^{9}$ Хантингтон С. Кто мы?: Вызовы американской национальной идентичности. Москва, 2004.

${ }^{10}$ Ibid. 50.
} 
are imaginary entities. They are what we think of ourselves, apart from cultural heritage (which can be renounced), gender (which can be changed), age (which, although cannot be changed, but can still be resisted); people are relatively free to choose their identity. But the traits that are inherited - including national identity - are flexible. They may change, obtain new signs" ${ }^{11}$.

Even the importance of identities can change over time, identities can complement each other or be in conflict. The perception of others also affects the self-identification of an individual or group. If a person finds himself in the new social context as an alien, then most likely he will consider themself a foreigner. "If a majority of the country's population considers a minority as, for example, uneducated and retarded, then members of that minority are likely to accept this attitude, whereby it becomes a part of their identity" ${ }^{12}$.

The outlined theoretical concepts of national identity formation are certainly not called to fully describe such a complex phenomenon; they can only become a basis for further studies of national identity. The phenomenon of national identity is one of the fundamental ones, it reflects the process of consolidation of nations, indicates the pressing challenges that society faces.

\section{The specifics of Ukrainian cultural identity}

Modern processes of globalization and the rapid change of sociopolitical conditions impact culture, transforming traditions and bringing new norms of their manifestation. Thus, there is a problem with the preservation of cultural originality and self-identification. The issue of cultural identity is particularly relevant in modern Ukraine, where the transformation of identity is caused not only by external influences but is also modified by the blurring of former value orientations, lack of consolidation in society, and thus by "identity conflict" ${ }^{13}$.

The most widespread is the definition of identity through a person's association with a cultural tradition. In our view, this definition is not complete, as the cultural tradition is only the accumulated, historically

\footnotetext{
${ }^{11}$ Хантингтон С. Кто мы?: Вызовы американской национальной идентичности. Москва, 2004. 52.

12 Ibid. 54.

${ }^{13}$ Радухин Ю: Национальная идентичность и вызовы XXI века. URL: http://www.3republic.org.ua/ru/ideas/11323 (дата звернення: 08.11.2019).
} 
inherited cultural achievements of a given society. They do not reflect the full diversity of the concept of "cultural identity".

In our opinion, American researcher Samuel Huntington was the closest to the full definition of cultural identity. By his definition, cultural identity is the totality of languages, religions, social and political values, social code, as well as public institutions and behavioral structures that reflect these elements.

Huntington clearly discerned cultural and ethnic identity. "Cultural identity can be transformed. Ethnic identity is almost non-transformable. Therefore, they should be clearly distinguished" ${ }^{14}$.

A person is not able to change his ancestors or skin color, so in this sense, ethnic heritage is interpreted as a given; however, a person can change the culture, move from one faith to another, accept new values and beliefs, identify with new symbols, adjust to a new way of life.

Accepting Huntington's views on cultural identity, we'll analyze Ukrainian cultural identity through language and religion as the most prominent components of identity.

In the discourse of Ukrainian identity, language is one of the most important, topical, and at the same time very sensitive issues for contemporary Ukraine. Language plays an important role in identity formation. Identification at the image-symbolic level, which is crystallized in the form of national consciousness and embodied as a symbol of faith for the people, takes place through identity. Since the common spheres of national existence are language, shared memory, and a faith-based outlook, then in the process of national identity formation the basic foundations are the common origin and common ancestors. But without developing common national interests and ideas, this process will be unfinished, because the past gives basis for the movement and its direction determines the purpose ${ }^{15}$.

Analyzing the impact of language on identity, it should be borne in mind that there are two languages, at least historically functioning, which impact Ukrainian cultural identity. The expansion of Russia's territory and the entry of most Ukrainian lands into the empire in the 17th-18th century opened a new stage of cultural interaction. At the same time, there was an awareness of objective significant differences. These

\footnotetext{
${ }^{14}$ Хантингтон С. Кто мы?: Вызовы американской национальной идентичности. Москва, 2004.

15. Окара А. Н, Украинские дискурсы и российская парадигма. Весник ТОГУ, 2007. № 3 (6), C. 44-48.
} 
differences manifested themselves in the 19th-early 20th century in the conditions of the rapid development of national ideology. Although LeftBank Ukraine was part of a single Russian space, the gradual awareness of the differences empowered the formation of a distinct cultural and linguistic ideology.

In the Western Ukrainian lands, a considerable part of which after the division of the Polish-Lithuanian Commonwealth became part of the Austrian monarchy, also underwent ethnonational identification processes.

Awareness of their community with the Russian people, or the aspiration of the Russian population of the monarchy to an independent Ukrainian people, that is, respectively, Russophilia (Moscophilia) and Ukrainophilia, were the main meaning of life of the East Slavic population of the Habsburg Monarchy in the second half of the 19th century and the beginning of 20th. For a long time, these directions developed in parallel and without apparent antagonism, however, over time, the differences between them increased. And the Ukrainian movement has developed a huge experience in the formation of national consciousness.

During the radicalization of the national movement and state-building on the Ukrainian lands, during the revolution and civil war, the features of the Ukrainian outlook obtained a completed form. This was especially facilitated by the processes in the 1920s-1930s. Bolshevik laws changed the status of the Ukrainian language; on the one hand legalizing it, on the other hand, forging a new system of values through ideology and politicization, overcoming existing cultural patterns and values that were considered a "relic of the past". The Soviet cultural policy was focused on building a new culture aimed at people's integration inside a united state.

Only after the collapse of the USSR fundamentally new processes began to take place in the Ukrainian cultural space. Activation of nationbuilding has led to a new attempt to form a cultural and linguistic identity.

Ukrainian ethno-cultural space has an ambivalent relation to the East and the West, which manifested itself in Ukrainian identity as a desire to distance itself from the "Russian and Polish heritage" and to outline own "glorious past", to emphasize own cultural and linguistic traits.

Thus, the language consciousness of Ukrainian people is based on the phenomenon of bilingualism. However, historically, despite RussianUkrainian bilingualism, different regions of Ukraine also have UkrainianPolish, Ukrainian-Hungarian, Ukrainian-Romanian bilinguals, and others. In this context, all residents of modern Ukraine are not so much divided but rather united by the language problem. But the problem is not with Russian or Ukrainian languages as such, but with the Russian-Ukrainian 
bilingualism, which is close to "duophony" (or polyphony), that is, when both languages are considered native: they are understood by the whole population, not perceived as foreign, not require translation and function within a single language system. The difference is that for the majority of residents of Western Ukraine, Russian is the second native, an for the East, the second native is Ukrainian. In the linguistic practices of central Ukraine, the balance is relatively equable and manifests itself in speaking of a mixture of languages called "surzhyk".

Ukrainian used to be the language of the vast majority of Ukrainians, Russian was the official language that served the official sphere, administration, education, as well as the language of "high culture". In modern Ukraine, everything is vice versa: the language of everyday communication is mostly "surzhyk", and Ukrainian is the official language in which the state communicates with citizens. The sphere of mass culture is dominated by Russian, and "high culture" is represented by Ukrainian. Generally, there is an agreement within Ukrainian society that both languages have a right to exist. Relatively conflicting is the problem of their real correlation, application, and functioning in various fields. Ukrainian political community as a whole obtained certain consensus regarding the language issue, with the exception of the political elite, who uses "language issue", gives it symbolic value and political "quotation" and turns into the subject of political manipulation.

Together with such an important factor in identity formation as a language, an important role is played by the religious factor. After all, any nation defines itself through religion no less than through language. Religion for centuries has been a powerful factor in bringing people together, a necessary component of individual and collective identity.

The religious and denominational composition of Ukrainian society is unique in its diversity. Despite the fact that Ukraine is a multidenominational country, none of those denominations can be considered as the national religion of Ukraine. Mykhailo Drahomanov criticized and condemned scholars and public figures who sought to associate a particular nationality with a particular religion. He was hostile to the official agenda of that day that identified Russians with Orthodoxy, Poles with Catholicism, Germans with Protestantism, and Slavs with Christianity in general. In a letter to Ivan Franko, he wrote: "Identification of any nationality with religion is nonsense" 16 .

${ }^{16}$ Драгоманов М. Л. Письма Ивана Франко и других 1881-1886 гг., Львов, 1906. 
First of all, let's note that Ukraine has always been dominated by a political factor over religious. Political figures most often turned not to the church that better reflected the national peculiarities of Ukrainians, but to the one that responded to their political aspirations. None of the denominations in the whole spectrum of their doctrines and rituals existed in Ukraine as a product of organic self-development of society. But in times of crisis in Ukraine, it was the religion that played the role of the institution that promoted cultural identification. We can say this about Ukrainian Orthodoxy as well as Uniatism, Catholicism, etc. Interfaith contradictions, though polarized Ukrainian people and impeded their national integration and self-determination, at the same time, played a role in the preservation of the Ukrainian ethnic group as such. It was confessional diversity that did not allow Ukrainians to be completely Russified or Polonized. The struggle for the "native faith" is, in essence, a struggle for the preservation of national and cultural identity. Therefore, we can conclude that the complexities of the historical existence of the Ukrainian people formed their pluralistic religious outlook, which influenced identity formation.

So, Ukrainian cultural identity exists as a set of linguistic, religious, value, political, behavioral orientations, none of which can be excluded from this complex, as the integrity of identity will be disrupted. But at the same time, there is a threat of loss of this integrity since the cultural identity is not a stable formation, it can be influenced by various factors - cultural standardization, globalization, universalization, etc. In addition to external influences, there are internal threats affecting the integrity of cultural identity as well: controversial attitudes of Ukrainians to issues of basic value orientations, such as integration with the EU, NATO, and relations with Russia. The formation of an adequate concept of national interests also becomes problematic. This can be a threat of assimilation of the nation and, accordingly, a threat to the integrity of Ukrainian cultural identity.

\section{Identity in the 21st century: challenges and perspectives}

In the 21st century, humanity has stepped into a new stage of development. First of all, globalization processes have induced the integration of humanity; social processes in one part of the world determine what is happening in the other, and universalization of culture is taking place. Modern socio-cultural context of identification processes is also influenced by the expansion of social interaction boundaries, 
the rapid development of information flows, high mobility of people, cultural diversity, emerging multicultural values, the formation of international labor and capital markets, transnational financial institutions, supranational political and economic organizations, blocs, unions, and other globalization processes. Realization of the sociopolitical changes and scenarios of future developments in a globalized world is impossible without defined identity orientations and analysis of identity transformations.

The crisis of national identity is widespread and has a global nature. In different countries this crisis takes different forms, differently develops and brings different consequences. But there are general trends that are typical for the entire globalizing socio-cultural space. Let's try to outline just some of them. Identification orientations are transformed under the influence of the global economy and the emergence of transnational corporations in the global market. National identity changes under the influence of transnational cosmopolitan identities. The integrated economy has given birth to a new global elite. "These elites are cosmopolitan. Today, these people move freely from country to country, and as a consequence, there is almost a complete loss of "localization of identity" both within one country and across the globe. Such people become multinational, that is, cosmopolitan"17. "The whole world becomes the arena of their activity... they are really citizens of the world" ${ }^{18}$. Therefore, it is obvious that the commitment to national identity and national interests is relatively small. Commitment to humanity as a whole becomes more significant than the commitment to the nation. A formation of certain "cosmopolitan ideal" takes place - an open society with "phantom borders, governed by elites who identify themselves mainly with global world institutions, norms, and rules". This aspiration for cosmopolitan identity implies a completely different level of national-state identity of the individual.

Today, there is an increase in global migration processes. Huntington writes of this: "There are powerful political forces that support dual citizenship, dual loyalties, dual identities. Many immigrants do not change one society to another and stand on two legs in two worlds" ${ }^{19}$. In his work, he gives multiple examples of the functioning of such

${ }^{17}$ Хантингтон С. Кто мы?: Вызовы американской национальной идентичности. Москва, 2004. 39.

18 Ibid. 419.

${ }^{19}$ Ibid. 325. 
communities in the United States. For example, the population of Chinantli (Mexico) is split between this tiny town and New York; at the same time, they consider themselves to be the joint community only 2500 people live in Mexico and the rest lives in America", contacts between them are permanent. Transnational settlements are united by social, religious and political ties that exist in both halves of ethnic communities.

An increase in the number of "semi-settlers" with two languages, two houses, two loyalties has led to a dual citizenship movement. The same situation has been taking place in recent years in Ukraine: residents of Bessarabia (south of the Odesa region) are actively receiving Bulgarian citizenship. Citizens of Bukovina are actively contacting and receiving Romanian citizenship. The same situation with Ukrainian Poles, Hungarians and others. Dual citizenship encourages communication with their countries and encourages their involvement in the social and political life of those countries. Double identity is becoming a feature of globalized space.

Thus, on the one hand, we observe almost a dissolution of national identity under the influence of globalization processes. On the other hand, globalization appears as a stimulant to nationalism. The rise of nationalism worldwide is one of the responses to the challenges of cultural globalism through the establishment of ethnocultural identity orientations. The "civilization imperialism" of modern globalization causes natural protests of peoples and nations who seek to preserve their cultural, denominational and other civilizational identities under the pressure of unification and standardization, and to support national spiritual values at any cost. In our view, it is the national culture that can act as the guardian of national identity and become its "visiting card" in the international arena.

Identity was also challenged by the technological breakthroughs of humanity. Comprehending the impact of modern scientific and technological progress on different aspects of human life, one should pay attention to the tendency of leveling of personality. The acceleration of technogenic civilization more and more complicates the system of socialization and personality formation. A constantly changing world, breaking many roots and traditions, forcing people to live in different cultures, to adapt to constantly updating situations. And such an important component as spirituality, the system of moral values and the identification of a person with these values are not sustainable. Today, the world filled with events only intensifies human uncertainty. 
Identity is strongly impacted by the dynamism of modern life, the unstable structure of social life, a wide choice of orientations, influenced by the mass media and migration processes. Information technology makes an unprecedented amount of information accessible and at the same time, it overwhelms the human, leaving only the small local islands of a truly learned experience. In this situation, it becomes more difficult for a person to self-define.

Open information space, the rapid development of network interconnections and high mobility have drastically changed the commitment of people involved in these processes and their perception of their place in the world. The globalized world continues to erode the sustained support of the nation-state. The national (country-oriented) component in the system of identification guidelines began to lose its past normative value for the positioning of the individual. Nations that until recently have been relatively closed in information sense (disconnected from other communities by linguistic, technical, communicative, political, ideological and other isolating means) have become more open. Their ability to interchange cultural forms increased, as well as the possibility to form systems of planetary communication and activity. However, likely, the global community will never be able to fully satisfy people's need for belonging, as it will never be able to become a fullfledged society because of the many different cultures and traditions. And that is why the idea of the world community, in our opinion, serves as an abstract universal construct, needed as the basis for the rules and institutions necessary for the coexistence of the many communities and their components. That is why an instinctive desire of different communities to preserve their own identity, which is most clearly manifested in the spheres of culture, national and religious consciousness (increasing trends of national consciousness, religious fundamentalism, ethnic separatism and extremism, the collapse of multinational empires and federations), is a natural the reaction to globalization. "Identity of the place" is a coordinated system, more important to many people as a significant psychological compensation for blurred orientations: it can support the necessary emotional or symbolic principles for the selfidentification of a person. Local identity (self-identification of a person with his or her small homeland, with a place of residence) is asserted in the open information space in the conscious and sometimes subconscious contradistinction to the depersonalized global symbols. The space category becomes one of the key concepts important for the understanding of trends of identity evolution. 
The revolution in communications, the emergence of Internet technologies, the expansion of the ability to receive and transmit information, the widespread adoption of mass communication created a situation when the system of social-existential positioning of a person loses its former distinctness and becomes the object of design both from themselves and from the outside. Essentially, identity construction takes place under the influence of the Internet.

Identity is something formed during primary socialization and the network begins to influence it since the initial engaging as a user. $\mathrm{Yu} . \mathrm{Yu}$. Lectorov in his article tries to answer the question: "Is there identity in the network?". He attempts to analyze the Internet as a particular sphere of identity construction. The information consumed by Internet users causes a change in the strategy of the positioning of particular individuals and societies in relation to the surrounding world. The symbolic image constructed by the network, in combination with the selected account parameters and specific nickname, acquire additional identification markers" ${ }^{20}$.

Thanks to the Internet, individuals can engage in a variety of cultural values as well as to start own cultural production. However, there are threats to information security, the dissemination of false information, pornography and so on. There may be a real threat to accepted moral values, the integrity of the nation, and the risk of loss of moral values and identity. Spiritual communications, connections, and values are deformed. They turn into anonymous information designed for an average consumer. In communication humanity loses dialogue, there is a "deficiency of humanity". Electronic media now have a total superiority over traditional media. They are the factors that shape the outlook of young people. And so there is a threat of changing the basic identities of a modern person and therefore of society, and actually of human civilization.

Information flows form virtual reality. The user consciously or unconsciously starts building own identification matrix. Besides, as a result of the exponential growth of users, a specific individual disappears from the information space and an impersonated user emerges. A network person turns into a software tool of virtual space that has

20 Лекторова Ю.Ю. Конструирование информационных повесток дня: выбор идентичности в Сети. Идентичность как предмет политического анализа. Сборник статей по итогам Всероссийской научно-теоретической конференции (ИМЭМО РАН, 21-22 октября 2010 г.). Научные редакторы И.С. Семененко, Л.А. Фадеева, П.В. Панов. М., ИМЭМО РАН, 2011. 158. 
unlimited manipulation capabilities. This raises the question of another value - freedom. Freedom and non-freedom in the global network is an antinomy also influencing identity formation, especially of youth. So, the technological nature of modern culture, the Internet and the virtual reality beget new cultural identities - unstable and diffuse.

\section{CONCLUSIONS}

Identity is a phenomenon that arises as a result of the interconnection between the individual, society, and culture. Currently, the problem of acquisition of identity can also be seen as a problem of freedom of choice, because the growth of an individual's intellectual and behavioral autonomy dramatically increases the degree of freedom. In previous epochs people united with others in rather stable groups, being guided by norms, ideas, values, fixed in the group culture. In today's society, social groups of different levels continue to exist, but the ties between the groups and the individuals within them are significantly weakened. The impetuosity of cultural shifts deprives the group ties of certainty and clarity. The situation of deconstruction of the world has raised the question of the search for a new identity, which will be not only holistic and systemic but also pluralistic in nature.

It was established that in the context of contemporary essential transformations in culture, the problem of "identity crisis" arises. The rapid nature of cultural shifts erodes cultural identities and creates a situation when people search for new ones. The causes of these processes are globalization and, as a consequence, the erosion of stable national identities. Dealing with that amount of problems in its study field, the science of culture must take the path of preserving national identity, which, by the demands of time, must be flexible, combined with other powerful ideologies and movements, and save its own character.

\section{SUMMARY}

In the study comprehension of identity in cultural discourse was made through an attempt to distinguish cultural identity. Cultural analysis has given us the possibility to define cultural identity through connection with norms, morals, values, traditions, religion, and language. Cultural identity emerges as self-awareness of a particular person within a particular culture, giving to the individual the stable qualities of the carrier of that culture.

We have outlined theoretical concepts of identity formation, first of all of national identity. National identity is the lens through which many relevant aspects of life are considered, evaluated and explored. 
The concept of "national identity" is a combination of objective and subjective features of a particular nation. The identity of nations is a set of features that unite certain communities within national borders, as well as internal qualities that determine the process of self-identification, distinguishing oneself among other nations. National identity can exist at both group and individual levels. Group identities are more stable, unlike more flexible individual identities. Individual identity, including individual national identity, is represented as a construct. Individuals, under the influence of various factors, can change their identities.

This study also highlighted specific features of Ukrainian cultural identity. The most significant are language, religion, shared memory, and a faith-based outlook. In the course of the historical progress of our culture, bilingualism was developed. At the image-symbolic level, it forms a double identity. The religious factor of identity formation is equally unique. Historically, there is a multi-confessional culture. None of the denominations in the whole spectrum of its doctrines and rituals existed in Ukraine as a product of organic self-development of society. However, at the same time, confessional diversity helped to preserve the Ukrainian ethnos as such, by forming a pluralistic religious outlook as a feature of Ukrainian national identity.

It was established that cultural and ethnic identity should be differentiated. Ethnos is a cultural and spiritual community of people, related in origin, language, cultural heritage, the territory of residence. At the same time, members of ethnic groups may consider themselves culturally different. That is, cultural identity can be transformed, but ethnic identity is not subjected to transformations, as ethnic heritage is perceived as a granted.

The formation of multicultural values, certain "cosmopolitan identification" takes place. And technological progress - the overflow of uncontrolled information, the Internet, the total and continuous invasion of virtual reality into our lives, causes a change in the strategy of positioning both individuals and national cultures.

\section{REFERENCES}

1. Андесон Б. Уявлені спільноти: міркування щодо походження і поширення націоналізму, Київ, 2001. 272 с.

2. Гидденс Э. Социология, Москва, 1999. 703 с.

3. Гнатенко П. И., Павленко В. П. Ідентичність: філософський і психологічний аналіз, Київ, 1999. 466 с. 
4. Драгоманов М. Л. Письма Ивана Франко и других 1881-1886 гг., Львов, 1906. 188. с.

5. Эриксон Э. Трагедия личности, Москва, 2008. 253 с.

6. Касьянов Г. Теорії нації і націоналізму, Київ, 1999. 352 с.

7. Лекторова Ю. Ю. Конструирование информационных повесток дня: выбор идентичности в Сети. Идентичность как предмет политического анализа. Сборник статей по итогам Всероссийской научно-теоретической конференции (ИМЭМО РАН, 21-22 октября 2010 г.). Научные редакторы И.С.Семененко, Л.А.Фадеева, П.В.Панов. М., ИМЭМО РАН, 2011. 345 с.

8. Окара А. Н, Украинские дискурсы и российская парадигма. Весник ТОГУ, 2007. №3 (6), С. 44-48.

9. Радухин Ю: Национальная идентичность и вызовы XXI века. URL: http://www.3republic.org.ua/ru/ideas/11323 (дата звернення: 08.11.2019).

10. Сміт Ентоні Д. Національна ідентичність. Київ, 1994. 224 с.

11. Хантингтон С. Кто мы?: Вызовы американской национальной идентичности. Москва, 2004. 635 с.

\section{Information about the author:}

Uvarova T. I., $\mathrm{PhD}$ in Arts, Associate Professor at the Department of arts and humanities studies, International Humanitarian University, 33, Fontanska Road St., Odessa, 65009, Ukraine 